\title{
Differences in the oral health behaviour of the 12-years-old children in rural and urban areas
}

\author{
Azkya Patria Nawawi*, Rina Putri Noer Fadilah*, Andi Supriatna* \\ *Department of Dental Public Health Dental Education Program Faculty of Medicine Universitas \\ Jenderal Achmad Yani, Indonesia
}

\begin{abstract}
Introduction: The oral diseases have increased significantly in the past decade. The Health Service of Cimahi reports showed an increasing number of oral diseases. Behaviour plays an important role in preventing oral disease. The purpose of this study was to examine the differences in the oral health behavior of the 12-years-old children in the rural and urban area of the city of Cimahi. Methods: The research type was analytic with the cross-sectional design. The sample was determined using pathfinder survey method from oral health surveys basic methods. Data were collected through a questionnaire containing knowledge and attitudes, observations of practice assessed in the checklist and assessment of the health status of the teeth using the Patient Hygiene Performance Data Index and analyzed using the Mann-Whitney test. Results: The results showed that children in both rural and urban areas were having a good knowledge and positive attitude. Both the rural and urban children were doing the improper tooth brushing methods, and the children in the rural area had a fair PHP index value whilst the children in the urban area had a poor value. There were significant differences in the knowledge $(p=0.017)$, there was no significant difference in the attitude $(p=0.312)$ and practice $(p=1.000)$ in children of both rural and urban areas. Conclusion: Difference only found in the oral health knowledge of the 12-years-old children in the rural and urban area of the city of Cimahi.
\end{abstract}

Keywords: Behaviour, oral health, 12-years-old, children

P-ISSN 1979-0201, e-ISSN 2549-6212 Available from: http://jurnal.unpad.ac.id/pjd/article/view/14517

DOI: 10.24198/pjd.vol29no3.14517

Submission: Sep 2017 Publishing: Nov 2017

\section{INTRODUCTION}

The oral diseases are still a big problem in Indonesia. Oral diseases place the sixth rank among the ten major diseases. The results from the Indonesia Basic Health Research reported in
2013 showed that the age of 10-14-years-old group had the rate of dental and oral health problems of $25.2 \%{ }^{1}$

The high prevalence of caries and periodontal diseases are mainly caused by various direct and indirect factors. Direct factors

Corresponding author: Azkya Patria Nawawi, Department of Dental Public Health Dental Education Program Faculty of Medicine Universitas Jenderal Achmad Yani, Jl. Ters. Jendral Sudirman, Jawa Barat, Indonesia; Email: Azkya patria@gmail.com 
are including microorganisms, carbohydrate fermentation, saliva, host defense, fluoride, and oral hygiene. Indirect factors are the external risk factors that are the predisposing factors and inhibiting factors of caries, including gender, education level, economic level, environment, and oral health behavior. ${ }^{2,3}$

According to Bahar in 2000, one of the main factors affecting the oral hygiene in developing countries is behavior. Behavior is an important thing that can affect the oral health status of individuals or communities. The efforts to improving the children's oral health also require the participation of the communities, through the improvement of the knowledge, attitudes, and actions which are the form of behavior, especially related to oral health such as dental health education through counseling. Dental and oral health behaviors are closely related and affect the improvement of the oral hygiene seen through the quantified oral hygiene status. ${ }^{3,4}$

The childhood period is a period of growth and development. The period of the tooth eruption begins at the age of 6 months, marked by the eruption of deciduous teeth. The complete period of permanent teeth occurs at the age of 12-yearsold. Therefore, this age period was considered as the ideal period, due to the easier accessibility before the children leave the elementary school. This condition was also based by the foundation from WHO that determined the age of 12-yearsold as global caries monitoring indicator period and also as an indicator of the development of dental and oral diseases (monitoring of disease trends). ${ }^{5}$

The reports from the Health Service of Cimahi stated that the high incidence of caries that reached 6992 teeth in the 12-years-old age group was caused by the bad behavior of dental and oral health care, and mostly occurred in children of the rural areas where health facilities were fewer than in the urban areas. ${ }^{6}$ The purpose of this study was to examine the differences in the oral health behavior of the 12-years-old children in the rural and urban area of the city of Cimahi.

\section{METHODS}

This study was an analytic cross-sectional study. The sample of this research was the sixth-grade of the elementary school students within the age group of 12-years-old. The study sample referred to the Pathfinder surveys from the WHO Oral Health Surveys Basic Methods, which was a stratified cluster sampling technique based on a subgroup with different levels. The examination of some standard subjects and included only specific age indexes. Groups were taken from geographical units (villages, sub-districts, urbanvillage, districts, etc. $)^{7}$ The sample used was the children from the age group of 12-years-old taken from each region representing rural and rural areas. From each region was being selected two districts representing the rural and urban areas. From each areas was being selected one school in with the total sample of 100 elementary school students ( 25 boys and 25 girls of the sixth-grade of the State Elementary School (SDN) of Cipageran, Northern Cimahi, as the urban elementary school representative; and the same amount of the sixthgrade of the Utama State Elementary School, Southern Cimahi, as the rural elementary school representative).

The inclusion criteria were as follows; elementary school children; within the age group of 12-years-old; having a full eruption of all permanent teeth until the first molar. The exclusion criteria were as follows; children with severe sickness (unable to open their mouth); being given topical fluoric applications; using an orthodontic plate or fixed orthodontic appliance. The behavior indicators examined were including the knowledge, attitudes, actions, and indexes. The measurement of the knowledge was using the closed-ended multiple choice questionnaire contained 15 questions, with the provisions as follows; for each correct answer was given the 1 score; for each wrong answer was given the 0 score. The measurement results then summed and divided by the number of questions and multiplied by $100 \%$. The final results were categorized into good category $(100-76 \%)$, fair $(56-75 \%)$ and poor $(<55 \%){ }^{8}$

The measurement of the oral health-related attitudes was performed by using questionnaires with the Likert scale, with each answer was given the value under the provisions as follows; for positive statements will be given the 4 value (strongly agree), 3 (agree), 2 (less agree), and 1 (disagree); for negative statements will be given 
the 1 value (strongly agree), 2 (agree), 3 (less agree), and 4 (disagree). The results then added and calculated the average score. The results of the individual values were categorized into two categories. The positive category if the value was higher than the average value, and the negative category if the value was lower than the average value.

The measurement of the oral health-related actions was performed by using the checklist of tooth brushing steps contained six steps of tooth brushing. The results were then categorized into two categories, if all actions were done correctly then will entered as the appropriate category, and if any of the actions were not done correctly then will entered as a not appropriate category. All instruments used were already tested for validity and reliability. The collected data was then processed and analyzed using the Mann-Whitney test (comparative test of 2 unpaired samples) with a significance level: $p \leq 0.05$; to see the differences in the two groups.

All analysis was done by using SPSS ${ }^{\circledR}$ v.22.0. This study has obtained ethical approval from Medical Ethics Board of Universitas Padjadjaran with Registration No. of 0815100804 . All subjects of the research have been given informed consent before every study and examination.

\section{RESULTS}

The categories of oral health knowledge from each group of children in the rural and urban areas were presented in Table 1.

The results of the study showed that most children in both rural and urban areas have a good and fair category of knowledge. In rural areas, as much as 37 children were having a good knowledge (74\%), whilst there were as much as 46 children in urban areas were having a good knowledge (92\%). It can be concluded that most of the children in the urban areas had better knowledge level than in the rural areas. Description of the oral healthrelated attitude of children in both rural and urban areas was presented in Table 2 below.

The results showed that the oral healthrelated attitude in the 12-years-old aged children in both rural and urban areas was positive. In the rural areas, there were as much as 32 children
(64\%), and as much as 27 children in the urban area were classified in this category. A description of the measurement results of the oral healthmaintaining action was presented in Table 3 .

The results of the Mann-Whitney test indicated that there was a significant difference between the knowledge $(p=0.017)$ of the children in the rural and the urban areas. However, the test results on the attitude $(p=0.312)$ and the action ( $p=1.000)$ of the children in the rural and the urban areas showed insignificant differences (Table 4).

Table 1. The oral health knowledge of the children in both rural and urban groups

\begin{tabular}{cccccccc}
\hline & \multirow{6}{*}{ No } & Region & \multicolumn{5}{c}{ Knowledge } \\
\cline { 3 - 8 } & characteristic & \multicolumn{2}{c}{ Good } & Moderate & \multicolumn{2}{c}{ Low } \\
\cline { 3 - 8 } & F & $\%$ & F & $\%$ & F & $\%$ \\
\hline 1 & Rural & 37 & 74 & 13 & 26 & 0 & 0 \\
2 & Urban & 46 & 92 & 4 & 8 & 0 & 0 \\
\hline
\end{tabular}

Table 2. The oral health attitude of the children in both rural and urban groups

\begin{tabular}{|c|c|c|c|c|c|}
\hline \multirow{3}{*}{ No } & \multirow{3}{*}{$\begin{array}{c}\text { Region } \\
\text { characteristic }\end{array}$} & \multicolumn{4}{|c|}{ Attiude } \\
\hline & & \multicolumn{2}{|c|}{ Positive } & \multicolumn{2}{|c|}{ Negative } \\
\hline & & Frequency & $\%$ & Frequency & $\%$ \\
\hline 1 & Rural & 32 & 64 & 18 & 36 \\
\hline 2 & Urban & 27 & 54 & 23 & 46 \\
\hline
\end{tabular}

Table 3. The oral health practice of the children in both rural and urban groups

\begin{tabular}{lccccc}
\hline & \multirow{2}{*}{$\begin{array}{c}\text { Region } \\
\text { No }\end{array}$} & \multicolumn{4}{c}{ Practice } \\
\cline { 3 - 6 } & characteristic & Proper & \multicolumn{3}{c}{ Improper } \\
\cline { 3 - 6 } & Rrequency & $\%$ & Frequency & $\%$ \\
\hline 1 & Rural & 0 & 0 & 50 & 100 \\
2 & Urban & 0 & 0 & 50 & 100 \\
\hline
\end{tabular}

Table 4. The Mann-Whitney test results in both rural and urban groups

\begin{tabular}{lccc}
\hline & $\begin{array}{c}\text { Behaviour } \\
\text { classification }\end{array}$ & groups & $\begin{array}{c}\text { Mann-Whitney } \\
\text { test }\end{array}$ \\
\hline 1 & Knowledge & Rural & 0.017 \\
& Urban & \\
2 & Attitude & Rural & 0.312 \\
& Urban & \\
& Practice & Rural & 1.000 \\
& & Urban & \\
\hline
\end{tabular}




\section{DISCUSSION}

Health behavior is the response of an individual related to the health problems, the use of health facilities, lifestyle, and the surrounding environment. ${ }^{7}$ Bloom's theory divides behaviors into three domains: knowledge, attitude, and action. ${ }^{4}$ The results of this study indicated that there was a significant difference in the knowledge of the 12-years-old children in the rural and the urban areas. Although both sample groups knowledge were in the good category, the percentage of such category in the rural areas was less than the urban areas (rural 74\%, and urban 94\%).

Sociological studies have shown a high distinction between knowledge, attitude, and action between the urban and rural groups. ${ }^{8}$ Research conducted in Burkina Faso, Africa, showed that the children in the urban areas were having a higher level of knowledge about dental and oral health. More intense parental education level, more active school teachers, and easier access to information in the urban areas were the explanation of the result of the study. ${ }^{9}$

In this study, the oral health-maintaining attitude of the children in the rural and urban areas was not significantly different. In the urban areas, the percentage of the positive oral healthmaintaining attitude was smaller than in the rural areas $(64 \%$ in the rural group compared to $54 \%$ in the urban group). Attitudes will change due to the knowledge change. ${ }^{4}$ The existence of the new and right information will provide a new knowledge foundation for the formation of the oral health-maintaining attitude of an individual. The information received will carry a suggestive message that becomes a powerful foundation for individual judgement and formation of certain attitude. ${ }^{12}$

Behavior is formed by a certain attitude. Behaviour is not determined by the general attitude, but by a specific attitude on responding certain thing. Behavior is not only influenced by a certain attitude, but also by a certain normative belief. ${ }^{13}$

The measurement of the oral hygiene results was not significantly different between the children in the rural areas and the urban areas. In fact, both were in the inappropriate category, therefore, can be concluded that the children in both areas have not done the proper tooth brushing technique. Appropriate tooth brushing technique is an important factor for the oral health care. This condition was also influenced by the proper frequency of tooth brushing, as well as the use of tooth brushing devices and methods. ${ }^{11}$

In a study conducted by Nurhidayat et al. in 2012 showed that in Indonesia, the people ignorance on the importance of oral health care was still high. This condition proofed by the rate of Indonesian people who was not brushing their teeth was as much as $22.8 \%$, and from $77.2 \%$ of the people were brushing their teeth only $8.1 \%$ of the people were brushing their teeth on the right frequency and time as recommended by dentists. ${ }^{14}$

\section{CONCLUSION}

Difference only found in the oral health knowledge of the 12-years-old children in the rural and urban area of the city of Cimahi.

\section{ACKNOWLEDGEMENT}

This research was fully supported by the Center for Research and Community Services of Universitas Jenderal Achmad Yani.

\section{REFERENCES}

1. National Institute of Health Research and Development (NIHRD). Indonesia Basic Health Research (RISKESDAS) 2013. Jakarta: Ministry of Health Republic of Indonesia; 2013.

2. Meyer-Lueckel H, Paris S, Ekstrand KR. Caries Management-Science and clinical practice. $1^{\text {st }}$ ed. Stuttgart: Thieme; 2013.

3. Warni L. Hubungan Perilaku Murid SD Kelas V dan VI Pada Kesehatan Gigi dan Mulut Terhadap Status Karies Gigi di Wilayah Kecamatan Delitua Kabupaten Deli Serdang [thesis]. Medan: USU; 2009.

4. Notoatmodjo S. Pendidikan dan perilaku kesehatan. $1^{\text {st }}$ ed. Jakarta: Rineka Cipta; 2010.

5. Hobdell M, Petersen PE, Clarkson J, Johnson N. Global Goals for Oral Health 2020. Int Dent J. 2003;53(5):285-8.

6. Dinas Kesehatan Pemerintah Kota Cimahi. Laporan Tahunan Program Kesehatan Gigi dan Mulut. Cimahi: Dinkes Pemkot Cimahi; 2016. 
7. World Health Organization. Oral Health Survey - Basic Methods. $5^{\text {th }}$ ed. Geneva: WHO Library Cataloguing-in-Publication Data; 2013.

8. Arikunto S. Prosedur Penelitian: Suatu Pendekatan Praktik. $6^{\text {th }}$ ed. Jakarta: Rineka Cipta; 2013.

9. Marya CM. A Textbook of Public Health Dentistry. $3^{\text {rd }}$ ed. New Delhi: Jaypee Brothers Medical Publishers (P) Ltd; 2011.

10. Pine $C M$, Harris R. Community Oral Health. $2^{\text {nd }}$ ed. Copenhagen: Quintessence; 2005.

11. Varenne B, Petersen PE, Ouattara S. Oral health behaviour of children and adults in urban an rural areas of Burkina Faso, Africa. Int Dent J. Apr 2006;56(2):61-70.

12. Al Subait AA, Alousaimi M, Geeverghese A,
Ali A, El Metwally A. Oral health knowledge, attitude and behavior among students of age 10-18 years old attending Jenadriyah festival Riyadh; a cross-sectional study. Saudi J Dent Res. Jan 2016;7(1):45-50. DOI: 10.1016/j. sjdr.2015.05.001

13. Rahmawati I, Hendrartini J, Priyanto A. Perilaku Kesehatan Gigi dan Mulut pada Anak sekolah dasar. J Comm Med Publ Health. 2011;27(4):180-6.

14. Nurhidayat $O$, Tunggul E, Wahyono $B$. Perbandingan media power point dengan flip chart dalam meningkatkan pengetahuan kesehatan gigi dan mulut. Unnes Journal Of Public Health. Jul 2012;1(1):31-5. DOI: 10.15294/ujph.v1i1.179. 